\title{
Climate change implications for the distribution of the babesiosis and anaplasmosis tick vector, Rhipicephalus (Boophilus) microplus
}

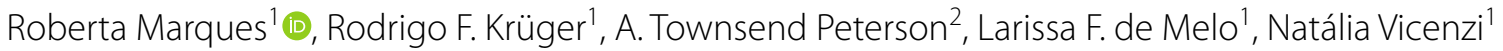 \\ and Daniel Jiménez-García ${ }^{3^{*}}$ (1)
}

\begin{abstract}
Climate change ranks among the most important issues globally, affecting geographic distributions of vectors and pathogens, and inducing losses in livestock production among many other damaging effects. We characterized the potential geographic distribution of the ticks Rhipicephalus (Boophilus) microplus, an important vector of babesiosis and anaplasmosis globally. We evaluated potential geographic shifts in suitability patterns for this species in two periods (2050 and 2070) and under two emissions scenarios (RCPs 4.5 and 8.5). Our results anticipate increases in suitability worldwide, particularly in the highest production areas for cattle. The Indo-Malayan region resulted in the highest cattle exposure under both climate change projections (2050), with increases in suitability of $>30 \%$. This study illustrates how ecological niche modeling can be used to explore probable effects of climate change on disease vectors, and the possible consequences on economic dimensions.
\end{abstract}

\section{Introduction}

Rhipicephalus (Boophilus) microplus is the most important tick in transmission of bovine parasitic diseases around the world [1]. The principal hosts for this species are cattle, but interactions have been shown with buffalo, horses, donkeys, dogs, deer, sheep, and goats [2-4]. High incidence of this tick is associated with economic losses, particularly in cattle [5]. This tick is responsible for transmission of the protozoa Babesia bovis and B. bigemina, and the bacterium Anaplasma marginale, which are the main pathogens of bovine babesiosis and anaplasmosis, respectively [6-8]. These diseases induce extreme emaciation in livestock, culminating in death.

\footnotetext{
*Correspondence: daniel.jimenez@correo.buap.mx

${ }^{3}$ Centro de Agroecología y Ambiente, Instituto de Ciencias, Benemérita Universidad Autónoma de Puebla, Puebla, Puebla, México

Full list of author information is available at the end of the article
}

Losses of US\$13-18 billion are caused by these pathogens globally each year $[9,10]$. Developing countries have seen the strongest consequences caused by $R$. microplus (e.g. in South America; $[5,11])$. Such countries generally lack effective control mechanisms for the tick, so that economic losses are exacerbated and livestock production is reduced markedly [12]. Estimates regarding milk losses caused by this tick species are $90.2 \mathrm{~L}$ per cow yearly; this reduction and losses in milk products generate production drops of around US\$922 million yearly [13]. Cattle at high risk regarding this tick are valued at US $\$ 3$ billion annually in Brazil alone [5], one of the most important developing countries in terms of livestock, responsible for exporting $\sim 43$ million tons of milk and meat [14].

Population growth and establishment are related to the following: (1) historical contingencies and geographic barriers [15]; (2) biological factors such as host

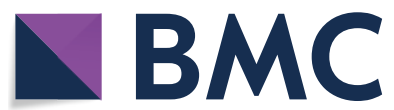

(c) The Author(s) 2020. This article is licensed under a Creative Commons Attribution 4.0 International License, which permits use, sharing, adaptation, distribution and reproduction in any medium or format, as long as you give appropriate credit to the original author(s) and the source, provide a link to the Creative Commons licence, and indicate if changes were made. The images or other third party material in this article are included in the article's Creative Commons licence, unless indicated otherwise in a credit line to the material. If material is not included in the article's Creative Commons licence and your intended use is not permitted by statutory regulation or exceeds the permitted use, you will need to obtain permission directly from the copyright holder. To view a copy of this licence, visit http://creativeco mmons.org/licenses/by/4.0/. The Creative Commons Public Domain Dedication waiver (http://creativecommons.org/publicdomain/ zero/1.0/) applies to the data made available in this article, unless otherwise stated in a credit line to the data. 
availability, competition; and (3) environmental conditions such as temperature and humidity [16, 17]. Future changes in climate include modifications of temperature and precipitation regimes; these environmental factors are crucial in delimiting species distributions and determining the success of population establishment [18]. Changes in these factors may modify the life cycle, abundance, and distribution potential for R. microplus $[19,20]$ and other disease vectors or species with importance in human and animal health [21-23]. Small changes at local levels can increase the risk of pathogen transmission [24]. Climate change generates a series of biological modifications in vector biology and consequently in pathogen incidence, which may lead to shifts in disease distributions [25].

Ecological niche models (ENM) are commonly used for understanding species' potential geographic distributions under different scenarios of environmental change [26-28], under Grinnell's niche concept [29]. The hypothesis of environmental factors being crucial in determining distributions of vectors and pathogens is supported amply by empirical studies [21, 22, 30-34]. However, many based-ENM studies of related disease arthropods have not used environmental variables related directly to the physiology of these species instead relying on general climate datasets that are easily available. In this paper, we assess possible potential areas for $R$. microplus under present-day and future climate conditions for two greenhouse gas emissions scenarios (RCP 4.5 and RCP 8.5) in two time periods (2050 and 2070), including a variable known to be crucial to the physiology of this species. We evaluate potential hotspots for this species and their coincidence with livestock concentrations to determine the most important risk areas under climate change for bovine parasitic diseases transmitted by this tick species.

\section{Materials and methods Occurrence data}

Occurrences were obtained from two different sources: (1) published data based on searches of different databases (Web of Science, Scopus, and Google Scholar); we used the keywords "Rhipicephalus", "Rhipicephalus microplus", "Boophilus microplus" and "Rhipicephalus (B.). microplus". We also obtained (2) data available on biodiversity information platforms: Global Biodiversity Information Facility [35], SpeciesLink [36], and VectorMap [37].

Data were collected for the period 1970-2018. Data lacking georeferencing (obtained mainly from published papers) were assigned coordinates via searches in Google Earth. We reduced biasing effects of spatial autocorrelation in occurrence data using a distance filter of $22 \mathrm{~km}$ in the spThin $\mathrm{R}$ package [38]. We chose a random $50 \%$ of the occurrence data for calibrating models, and used the remaining $50 \%$ to evaluate the models. Our initial 1487 occurrences for $R$. microplus in America reduced to 531 with spatial filtering (Figure 1). We also considered occurrence data for this species from Africa [39, 40]; these 145 African occurrences were used as independent evaluation data, with the same spatial filter, for an additional model evaluation.

\section{Environmental data}

We used 15 bioclimatic variables from WorldClim version 1.4 (Table 1) [41], excluding four variables known to include spatial artefacts [42]. WorldClim variables were derived from climatic data for 1950-2000. To add a variable known to be important to the physiology of this species [43], we obtained relative humidity ( $\mathrm{RH}$ ) from the Coupled Model Intercomparison Project [44], which we downscaled by the Delta Method, commonly used in climate data [45]. To summarize future conditions, we used outputs from 20 general circulation models (GCM) available from Climate Change, Agriculture and Food Security [46] (Additional file 1). We used two greenhouse gas emissions scenarios (RCP 4.5 and RCP 8.5) for two time periods (2050 and 2070) to explore model-to-model variation. The environmental data were used at a spatial resolution of $0.2^{\circ}(\sim 22 \mathrm{~km})$ under both present-day and future conditions. Dimensionality was reduced by calculating Pearson correlations over the entire calibration area, removing one from each pair of variables with correlations $\geq 0.80$. Uncorrelated variables were according to different variable sets: we used all possible variable combinations (120 sets) for model calibration and evaluation [47]. Variables used as candidates for inclusion in models therefore included annual mean temperature, temperature seasonality, minimum temperature during the coldest month, annual precipitation, precipitation during the driest month, precipitation seasonality, and relative humidity.

\section{Model calibration and evaluation}

Models were calibrated with the kuenm $\mathrm{R}$ package, running [48] Maxent 3.4.1 [49] and using model selection approaches [50]. We used significance, performance (omission rate), and model complexity to choose optimal parameter settings from among candidate models. All possible combinations of linear (l), quadratic (q), product $(\mathrm{p})$, threshold $(\mathrm{t})$, and hinge $(\mathrm{h})$ feature types were tested, as were different regularization multiplier values $(0.1,0.3$, $0.5,0.7,1,2,3,5,7$, and 10). Models are built using all possible combinations of the seven environmental variables. Hence, we explored a total of 5400 candidate models. Significance testing was via partial ROC [51], with 


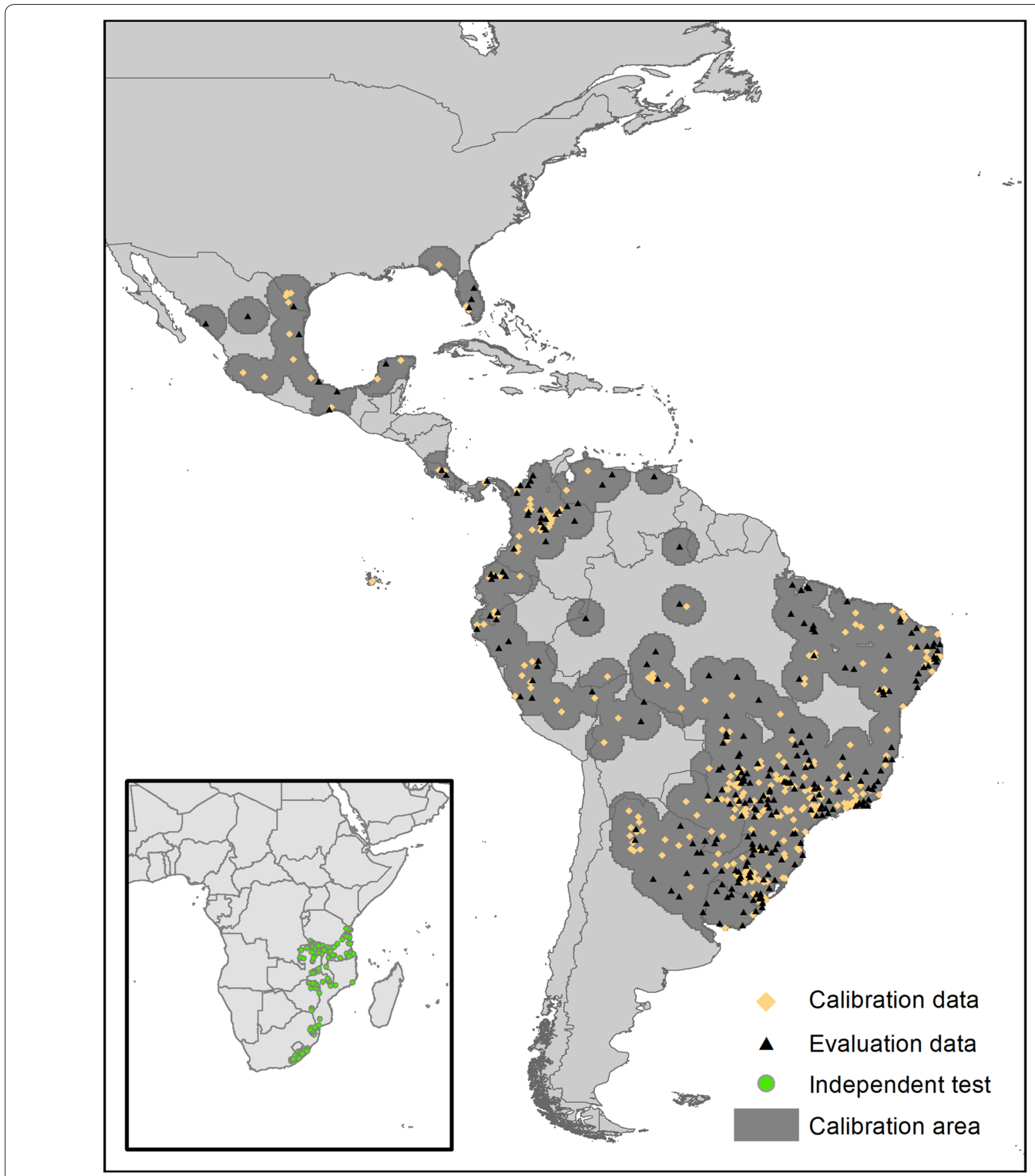

Figure 1 Calibration area and the known distribution of Rhipicephalus (Boophilus) microplus (points). Occurrence records used in model calibration (test and training) are shown; occurrences in Africa were used as independent data to evaluate the accuracy of model transfer worldwide.

acceptable omission error of $E=0.05$. Finally, we evaluated the model complexity using the Akaike information criterion with a correction for small sample size (AICc), via a code derived from Warren et al. [50].

We used the accessible area concept as a means of choosing the area over which to calibrate our models [15,
52], using a buffer of $200 \mathrm{~km}$ around occurrence data as a proxy to this area (Figure 1). Final models were summarized as the median of 10 bootstrap replicates of the model corresponding to the best model parameter set, and transferred to future conditions worldwide. We used the kuenm package [48] both to evaluate final models and 
Table 1 Climate variables used in ecological niche modeling of current and future potential distributions of Rhipicephalus (Boophilus) microplus

\begin{tabular}{|c|c|c|}
\hline Acronym & Description & $\begin{array}{l}\% \text { variable } \\
\text { contribution }\end{array}$ \\
\hline $\mathrm{Bio} 1^{\mathrm{a}}$ & Annual mean temperature & 26.6 \\
\hline $\mathrm{Bio} 2$ & Mean diurnal range & \\
\hline $\mathrm{Bio3}$ & Isothermality & \\
\hline $\mathrm{Bio}^{\mathrm{a}}$ & Temperature seasonality & 21.4 \\
\hline $\mathrm{Bio5}$ & Maximum temperature of warmest month & \\
\hline Bio6 & Minimum temperature of coldest month & \\
\hline Bio7 & Temperature annual range & \\
\hline $\mathrm{Bio}^{\mathrm{b}}$ & Mean temperature of wettest quarter & \\
\hline$B i o 9^{b}$ & Mean temperature of driest quarter & \\
\hline Bio10 & Mean temperature of warmest quarter & \\
\hline Bio11 & Mean temperature of coldest quarter & \\
\hline $\mathrm{Bio} 12^{\mathrm{a}}$ & Annual precipitation & 14.6 \\
\hline Bio13 & Precipitation of wettest month & \\
\hline Bio14 & Precipitation of driest month & 19.2 \\
\hline Bio15 & Precipitation seasonality & \\
\hline Bio16 & Precipitation of wettest quarter & \\
\hline Bio17 & Precipitation of driest quarter & \\
\hline Bio18 & Precipitation of warmest quarter & \\
\hline $\mathrm{Bio19}$ & Precipitation of coldest quarter & \\
\hline $\mathrm{RH}^{\mathrm{a}}$ & Relative humidity & 18.1 \\
\hline
\end{tabular}

Bioclimatic variables from the WorldClim data archive (version 1.4; Hijmans et al. [41]) and relative humidity [44] were used for modeling. Five variables ${ }^{\mathrm{a}}$ were selected for modelling via our model selection processing [47].

b Variables excluded because they have unrealistic spatial artefacts [42].

to transfer models to future conditions. Areas presenting extrapolative conditions were identified with a MOP analysis [53], comparing conditions between calibration and transfer areas across the $20 \mathrm{GCM} \times 2 \mathrm{RCPs} \times 2$ time periods that made up our future scenarios.

Model transfers were summarized and simplified via a binarization process. Median model transfers were binarized using an acceptable omission rate of $E=0.05$. Binary maps were used to determine climate uncertainty in the models, which we summarized as agreement among multiple scenarios between present and future to determine areas of stability. We used a threshold of $\geq 60 \%$ (12) of agreement among GCM as a relatively clear signal of presence or absence of suitable conditions. Finally, to provide an additional model evaluation, we used occurrence data from the African range as an evaluation of the model's predictive ability. We obtained cattle abundance data from the Food and Agriculture Organization of the United Nations (FAO) [54] and Robinson et al. [55] to evaluate implications of future changes in the range of the tick for cattle production. We used different categories (cattle abundances: Additional file 2) to evaluate possible impacts of the tick under future projections. We evaluated the highest potential range expansion of the tick with regards to the different world cattle production areas.

\section{Results}

We evaluated 5400 candidate models; 3687 of these models were statistically significant $(P<0.05)$, of which 1348 showed good performance (i.e., omission error $\leq 0.05$ ); however, a single model was selected on the basis of low complexity $(\mathrm{AICc}=10,398.67)$, in that the difference in AICc between it and the next best model was large (26.4786). The best model included all feature types (lqpth: Linear, Quadratic, Product, Threshold and Hinge) with a regularization parameter of 1 . Variables selected were annual mean temperature, temperature seasonality, annual precipitation, precipitation of driest month, and relative humidity (Table 1). The biggest relative contribution of environmental variables to the model was from annual mean temperature (26.6\%), whereas the smallest contribution was from annual precipitation (14.6\%; Table 1). Our independent evaluation (i.e., predicting the African distribution) was significantly different from random predictions according to the pROC evaluation $(P<0.001)$. Omission rate was $7.5 \%$, with only 11 failures out of 145 evaluation points.

In the Americas, the present-day model shows high suitability for $R$. microplus in North and South America: in Brazil (central, western, southern), Uruguay (northern), Argentina (northern, eastern), and across Central America, Mexico, and the southern USA (Figure 2). Models also indicate high suitability across much of subSaharan Africa, except for the interior of South Africa and Botswana. Western Europe, Southeast Asia, and coastal parts of Australia also had high suitability (Figure 2), especially inside the calibration area.

Model transfers to future conditions (Additional files 3, 4, 5 and 6) show high stability of suitability in currently suitable regions, and increases of suitability in the Neotropics (Argentina, Brazil, Colombia, Venezuela), Eurasia (northern and eastern Europe; Indo-Malayan Region (India, Bhutan, Nepal, Myanmar, China), North America (Mexico, southeastern USA), and including Afrotropics (West Africa, Sudan, South Sudan, Chad). Under a moderate climate change scenario (RCP 4.5) we noted increases in suitability with low uncertainty by 2050 and 2070 (Additional files 3 and 4); some areas of South America (e.g., Amazonas state in Brazil) show increased suitability. Under the high-emissions scenario (RCP 8.5), in 2050, increases in suitability were broadly distributed in the Nearctic, Neotropics, Palearctic, Afrotropics, and the Indo-Malayan region (Additional files 3 and 5). For 2070 (Additional files 4 and 6), increases in suitability 


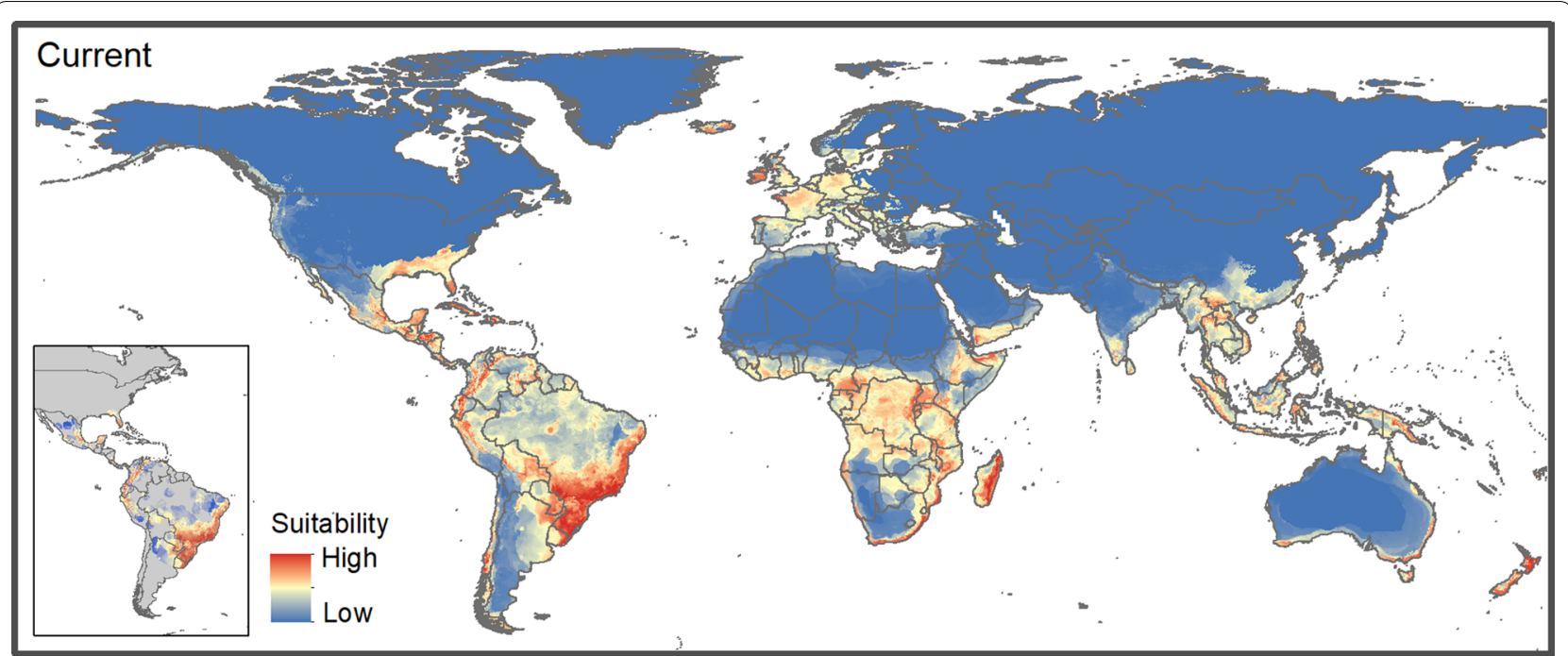

Figure 2 Present-day suitability for Rhipicephalus (Boophilus) microplus according to the best ecological niche model, under current conditions and calibration area (detail).

were in much the same regions. The areas that presented extrapolation risk from the calibration area are shown in Figure 3.

Our models show high suitability in the present day, and increases in suitability in the future, in places with the highest abundances of cattle around the world (Tables 2 and 3, Additional file 2). Low cattle abundances (0 to 1 individuals $/ 10 \mathrm{~km}^{2}$ ) were the areas most likely to see increases in suitability for the tick, with a possible increase of $\sim 21 \%$ in the world for this category (Tables 2 and 3); the Palearctic, Neotropical, and IndoMalayan regions were those most likely to see increases in suitability. Highest cattle abundances ( $>100$ individuals $/ 10 \mathrm{~km}^{2}$ ) in the Indo-Malayan region were projected to see suitability increases of $\sim 34 \%$ in 2050 and $~ 16 \%$ in 2070 (Tables 2 and 3). All study regions show increases in suitability ( $\sim 1 \%$ to $\sim 134 \%)$; major changes were noted in the Nearctic Region (Tables 2 and 3).

\section{Discussion}

Babesiosis and anaplasmosis may be related to the same environmental factors as $R$. microplus because they depend on this tick as a main vector [6-8]. Different wild animals serve as hosts for this tick; the best-studied is the white-tailed deer Odocoileus virginianus [3]: livestock reservoirs of these pathogens include goats [4]. Host species are important for dispersal, although this tick is not a specialized ectoparasite; this generalist habit facilitates dispersal by wild and livestock animals [6-8].

The potential distribution of $R$. microplus is related to a diverse suite of ecological and environmental factors around the world $[1,17,19,20,56-60]$. Moreover, in order for the tick populations to spread in a region, individuals must first be introduced, then go through a phase of adaptation to the local hosts and then reach a population density that allows mating and reproductive success of adults $[1,31,58]$. Complex relationships with other species, especially wild hosts, are particularly relevant for individual dispersal and population occurrence in suitable environments $[3,61]$. Our models show suitable areas in Europe and Asia, places without species present; however, the environmental conditions correspond to species establishment. Climate factors affect the ticks life cycle and geographic distribution [62,63]. The most important factors identified in our model construction were annual mean temperature, precipitation seasonality, and relative humidity [17].

Climate seasonality is an important factor in the $R$. microplus life cycle; variation in this factor influence the number of generations (three to four per year), increasing the population size and potentially facilitating dispersal $[62,63]$. We found important environmental variables similar to those identified in field analyses of this species [17]. Annual mean temperature, seasonality in precipitation, and variables derived from humidity were crucial to these models [17]; however, no previous study has used relative humidity in model construction, which is a fundamental variable affecting this species' development [64, 65].

Currently, R. microplus does not occur in some regions that our models signaled as suitable, which can be explained by several factors; for example: (1) some trophic activities or other biological interactions that reduce the possibility of occurrence in Europe, Australia, 


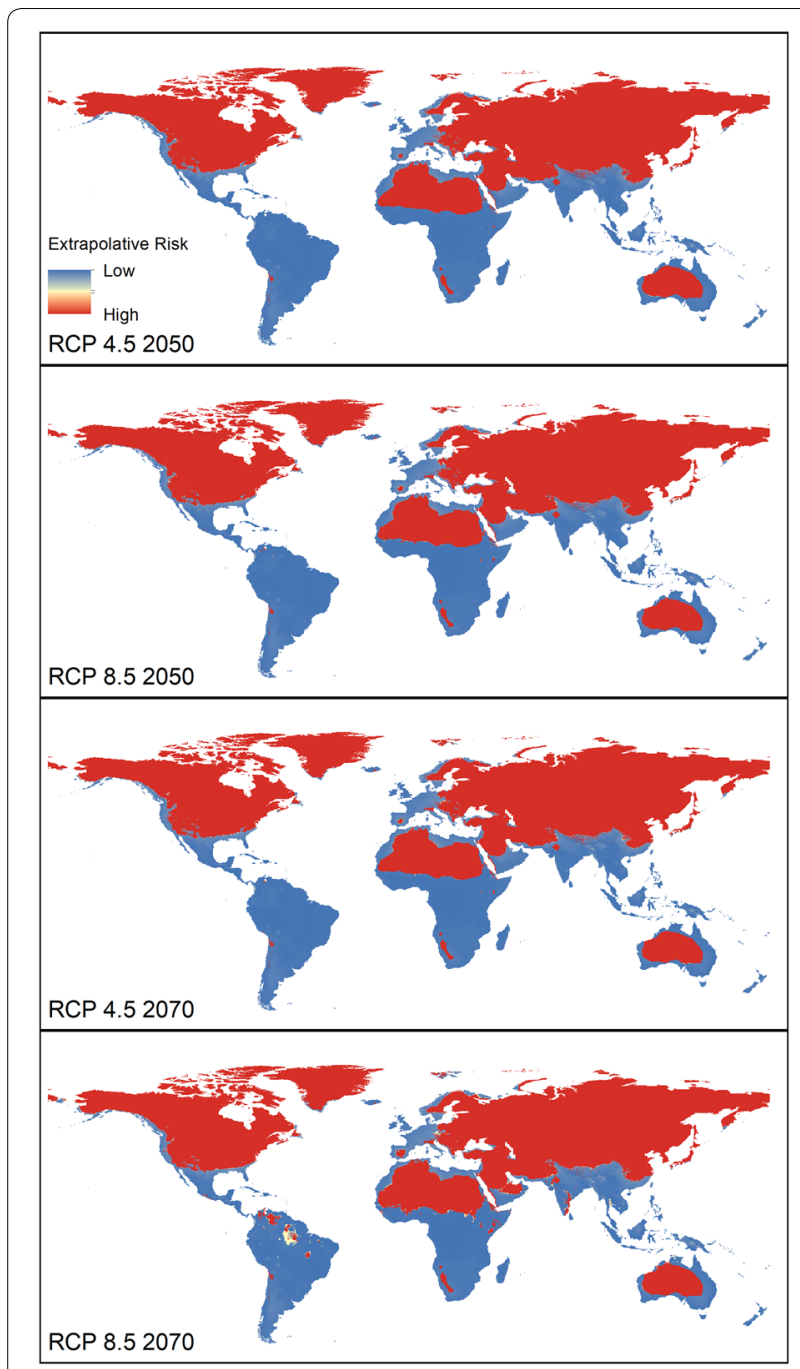

Figure $3 \mathrm{MOP}$ analysis of extrapolation risk from the calibration area under current conditions to the whole world under future conditions. Blue values represent strict extrapolative areas. Red values represent levels of similarity between the calibration area and the different RCPs scenarios of projections.

and parts of northern Asia. (2) Historical conditions in particular, major dispersal barriers, decrease the access of this species to Europe, Australia, and northern Asia. In addition, for the species to be introduced into these areas, it is important to consider the number of individuals required to overcome demographic limitations and produce permanent populations, sufficient host density to support tick populations, and immune responses of the host [17].
Economic losses in cattle are generated by tick infestations in cattle herds around the world. Countries with high cattle populations have experienced significant losses in meat production (e.g., Brazil, with US $\$ 3.4$ billion per year [5]; Tanzania, with US\$364 million per year [66]; and Mexico, with US\$573 million per year [67]). Thirtyeight percent of the world's cattle population is located in India; babesiosis is a common disease there, driving important economic losses [68]; indeed, $\sim 4 \%$ of cattle in northeastern India died from this disease [69]. Our results anticipate increases in suitability for the tick, particularly in northern India, potentially increasing losses under future climates (Tables 2 and 3, Figures 2 and 3 , Additional files 3 and 4). The Indo-Malayan regions include several countries with high potential cattle exposure showing increases in tick suitability (Additional files 3 and 4) and high abundances of cattle, particularly south India, Sri Lanka, Myanmar and Thailand (Tables 2 and 3, Additional file 2). Increases in suitability for the tick in West Africa (Côte d'Ivoire, Benin), increases cattle exposure to babesiosis and anaplasmosis [31]; of particular note is that importation of Brazilian cattle in these countries creates a situation optimal for tick establishment a situation confirmed by independent models from De Clercq et al. [31].

Changes in the potential distribution of this tick in relation to climate change have been discussed and documented in previous studies $[17,19,56]$. However, our work used an uncertainty evaluation that explored 20 GCM, two greenhouse gas emission scenarios, and two time periods (Additional files 3 and 4): we also used independent data for model testing (from Africa) and incorporated novel data on relative humidity. Our model is strongly consistent and accurate (Additional files 3, 4, 5), but has two strong limitations. (1) We did not include biotic factors (interactions) in the model, especially because this species requires a host; however, given the broad host range of this tick, we did not have any logical means of assessing all the different possible hosts in the world. (2) We did not consider relationships between numbers of ticks and numbers of cattle in different regions of the world. However, our models provide a view of suitability for the tick under future conditions, which we translate into metrics of cattle exposure for different cattle populations worldwide. The results were consistent with future potential increases of this invasive species around the world, despite the biotic factors not evaluated in our models (e.g. vegetation, host availability and biological interactions). 
Table 2 Proportion of modification of $\boldsymbol{R}$. microplus suitability to climate change scenarios according to zoogeographic regions and livestock abundance categories worldwide [54, 55] for 2050 scenarios

\begin{tabular}{|c|c|c|c|c|c|c|c|c|c|}
\hline \multirow[t]{2}{*}{ Scenarios } & \multirow[t]{2}{*}{ Regions } & \multicolumn{8}{|c|}{ Cattle abundance (individuals $/ 10 \mathrm{~km}^{2}$ ) } \\
\hline & & $0-1$ & $1-5$ & $5-10$ & $10-20$ & $20-50$ & $50-100$ & $>100$ & $\begin{array}{l}\text { All } \\
\text { categories } \\
\text { (average) }\end{array}$ \\
\hline \multirow[t]{6}{*}{ RCP 4.5} & Afrotropic & 1.57 & 5.78 & 6.47 & 6.23 & 5.86 & 6.93 & 7.75 & 5.80 \\
\hline & Australasia & 6.26 & 6.10 & 0.91 & 1.41 & 9.94 & 7.81 & 3.99 & 5.20 \\
\hline & Indo-Malayan & 3.02 & 2.82 & 3.55 & 3.27 & 5.64 & 11.44 & 31.55 & 8.76 \\
\hline & Nearctic & 16.09 & 3.62 & 2.87 & 4.52 & 4.40 & 2.46 & 25.48 & 8.49 \\
\hline & Neotropic & 9.42 & 5.71 & 4.87 & 5.61 & 5.70 & 4.44 & 8.95 & 6.39 \\
\hline & Palearctic & 9.05 & 2.83 & 3.22 & 4.32 & 3.13 & 0.79 & 0.49 & 3.40 \\
\hline \multirow[t]{6}{*}{ RCP 8.5} & Afrotropic & 0.60 & 1.96 & 1.33 & 2.19 & 1.98 & 1.23 & 1.72 & 1.57 \\
\hline & Australasia & 1.53 & 0.50 & 0.06 & 0.16 & 0.61 & 0.00 & 0.00 & 0.41 \\
\hline & Indo-Malayan & 3.39 & 2.34 & 4.24 & 4.36 & 6.04 & 6.54 & 6.28 & 4.74 \\
\hline & Nearctic & 33.12 & 2.50 & 1.90 & 1.62 & 5.65 & 32.89 & 134.87 & 30.36 \\
\hline & Neotropic & 2.69 & 2.68 & 2.40 & 2.33 & 1.90 & 1.29 & 0.59 & 1.99 \\
\hline & Palearctic & 22.88 & 26.74 & 12.78 & 10.35 & 6.61 & 4.80 & 1.78 & 12.28 \\
\hline \multirow[t]{6}{*}{ Both } & Afrotropic & 4.58 & 10.21 & 14.19 & 11.24 & 7.80 & 7.77 & 9.97 & 9.39 \\
\hline & Australasia & 13.65 & 5.97 & 8.18 & 7.26 & 9.26 & 7.92 & 2.91 & 7.88 \\
\hline & Indo-Malayan & 25.17 & 12.77 & 11.14 & 11.91 & 18.24 & 20.53 & 34.57 & 19.19 \\
\hline & Nearctic & 50.34 & 4.25 & 2.50 & 1.68 & 2.35 & 8.62 & 3.01 & 10.39 \\
\hline & Neotropic & 29.87 & 13.68 & 12.14 & 9.71 & 7.82 & 5.44 & 8.87 & 12.50 \\
\hline & Palearctic & 32.03 & 40.84 & 18.65 & 15.71 & 13.09 & 8.95 & 4.51 & 19.11 \\
\hline
\end{tabular}

Values with increases greater than $10 \%$ are shown in italics.

Table 3 Proportional modifications of Rhipicephalus (Boophilus) microplus suitability to climate change scenarios divided by zoogeographic regions and livestock abundance categories worldwide [54, 55] for 2070 scenarios

\begin{tabular}{|c|c|c|c|c|c|c|c|c|c|}
\hline \multirow[t]{2}{*}{ Scenarios } & \multirow[t]{2}{*}{ Regions } & \multicolumn{8}{|c|}{ Cattle abundance (individuals $/ 10 \mathrm{~km}^{2}$ ) } \\
\hline & & $0-1$ & $1-5$ & $5-10$ & $10-20$ & $20-50$ & $50-100$ & $>100$ & $\begin{array}{l}\text { All } \\
\text { categories } \\
\text { (average) }\end{array}$ \\
\hline \multirow[t]{6}{*}{ RCP 4.5} & Afrotropics & 3.23 & 8.86 & 10.68 & 10.75 & 9.04 & 5.10 & 1.96 & 7.09 \\
\hline & Australasia & 7.09 & 7.30 & 2.97 & 3.51 & 9.65 & 0.90 & 2.60 & 4.86 \\
\hline & Indo-Malayan & 5.73 & 6.43 & 8.60 & 7.84 & 11.35 & 16.99 & 47.84 & 14.97 \\
\hline & Nearctic & 11.66 & 2.19 & 1.81 & 2.03 & 1.22 & 0.82 & 0.00 & 2.82 \\
\hline & Neotropics & 19.67 & 11.25 & 11.39 & 9.47 & 8.88 & 6.95 & 11.44 & 11.29 \\
\hline & Palearctic & 6.60 & 6.31 & 5.16 & 5.63 & 3.19 & 1.64 & 0.48 & 4.15 \\
\hline \multirow[t]{6}{*}{ RCP 8.5} & Afrotropics & 0.09 & 0.81 & 0.50 & 0.75 & 1.16 & 4.03 & 5.97 & 1.90 \\
\hline & Australasia & 5.19 & 1.71 & 0.47 & 0.26 & 0.32 & 0.76 & 0.10 & 1.26 \\
\hline & Indo-Malayan & 6.03 & 1.50 & 1.94 & 2.17 & 2.51 & 4.81 & 3.47 & 3.20 \\
\hline & Nearctic & 86.15 & 2.25 & 1.11 & 0.78 & 1.73 & 4.97 & 4.03 & 14.43 \\
\hline & Neotropics & 0.95 & 2.02 & 1.33 & 1.45 & 1.76 & 1.06 & 0.09 & 1.24 \\
\hline & Palearctic & 39.17 & 38.77 & 26.97 & 18.92 & 13.40 & 4.01 & 2.68 & 20.56 \\
\hline \multirow[t]{6}{*}{ Both } & Afrotropics & 2.05 & 3.96 & 6.83 & 4.66 & 3.68 & 6.87 & 11.02 & 5.58 \\
\hline & Australasia & 10.49 & 3.33 & 8.50 & 7.70 & 13.94 & 10.34 & 7.29 & 8.80 \\
\hline & Indo-Malayan & 18.37 & 10.01 & 9.32 & 9.93 & 15.52 & 13.45 & 16.74 & 13.33 \\
\hline & Nearctic & 77.68 & 4.88 & 1.88 & 1.39 & 1.23 & 5.50 & 3.01 & 13.65 \\
\hline & Neotropics & 14.48 & 5.44 & 5.14 & 4.15 & 3.31 & 1.91 & 3.70 & 5.45 \\
\hline & Palearctic & 38.34 & 42.56 & 21.47 & 23.21 & 18.73 & 13.60 & 6.33 & 23.46 \\
\hline
\end{tabular}

Values $\geq 10 \%$ are shown in italics. 


\section{Supplementary information}

Supplementary information accompanies this paper at https://doi. org/10.1186/s13567-020-00802-z.
Additional file 1. General circulation models used in ecological niche modeling projections in RCP 4.5 and RCP 8.5 for 2050 and 2070 .

Additional file 2. Cattle abundances categorized from FAO and Robinson et al. [54] from different zoogeographic regions in the world to evaluate Rhipicephalus (Boophilus) microplus suitability in each of them under future climate change and present-day scenarios. Abundances are represented by number of individual heads of cattle per $10 \mathrm{~km}^{2}$.

Additional file 3. Current and potential future distributions of Rhipicephalus (Boophilus) microplus for two emissions scenarios (top, RCP 4.5; bottom, RCP 8.5) in 2050. Dark blue: areas predicted to be suitable in present-day and with a strong chance of suitability in the future $(>12$ GCM). Light blue: areas predicted to be suitable in present-day but with reduced probability of presence in the future (<12 GCM). Red: areas unsuitable in the present-day, but with a strong chance of suitability in the future (>12 GCMs). Pink: areas predicted to be unsuitable in present-day but have slight chance of suitability in the future (<12 GCM). White: areas unsuitable in both present-day and future scenarios.

Additional file 4. Current and potential future distributions of Rhipicephalus (Boophilus) microplus for two emissions scenarios (top, RCP 4.5; bottom, RCP 8.5) in 2070. Dark blue: areas predicted to be suitable in present-day and with a strong chance of suitability in the future $(>12$ GCM). Light blue: areas predicted to be suitable in present-day but with reduced probability of presence in the future ( $<12$ GCM). Red: areas unsuitable in the present-day, but with a strong chance of suitability in the future (>12 GCM). Pink: areas predicted to be unsuitable in present-day but with a slight chance of suitability in the future (<12 GCM). White: areas unsuitable in both present-day and future scenarios.

Additional file 5. Suitability for Rhipicephalus (Boophilus) microplus in 2050 under RCP 4.5 and 8.5 according to the best ecological niche model.

Additional file 6. Suitability for Rhipicephalus (Boophilus) microplus in 2070 under RCP 4.5 and 8.5 according to the best ecological niche model.

\section{Acknowledgements}

We thank members of the Peterson and Soberón labs at the University of Kansas for myriad assists with different dimensions of the data analysis for this study. Daniel Jiménez-García was funded by the Fulbright Visiting Scholar Program-Senior Scholar. We thank the Conselho Nacional de Desenvolvimento Científico e Tecnológico (CAPES) for financial support for the first author's Ph.D "sandwich" program (Process: 47/2017). We thank the Conselho Nacional de Desenvolvimento Científico e Tecnológico (CNPq) for financial support to Rodrigo F. Krüger (Process: 308908/2016-3).

\section{Authors' contributions}

RM, RFK, and DJG conceived the project and planned the study. LFM and NV collected data. RM and DJG conducted research and data analysis. RFK, RM, ATP, and DJG composed the manuscript. All authors read and approved the final manuscript.

\section{Competing interests}

The authors declare that they have no competing interests.

\section{Author details}

${ }^{1}$ Laboratório de Ecologia de Parasitos e Vetores, Programa de Pós Graduação em Microbiologia e Parasitologia, Departamento de Microbiologia e Parasitologia, Instituto de Biologia, Universidade Federal de Pelotas, Pelotas, RS, Brazil. ${ }^{2}$ Biodiversity Institute, University of Kansas, Lawrence, KS, USA. ${ }^{3}$ Centro de Agroecología y Ambiente, Instituto de Ciencias, Benemérita Universidad Autónoma de Puebla, Puebla, Puebla, México.
Received: 16 September 2019 Accepted: 29 April 2020

Published online: 17 June 2020

\section{References}

1. Estrada-Peña A, Bouattour A, Camicas J-L, Guglielmone A, Horak I, Jongejan F, Latif A, Pegram R, Walker AR (2006) The known distribution and ecological preferences of the tick subgenus Boophilus (Acari: Ixodidae) in Africa and Latin America. Exp Appl Acarol 38:219-235

2. Brito DRB, Santos ACG (2005) Ectoparasitos em rebanhos de caprinos e ovinos na microrregião do Alto Mearim e Grajau, Estado do Maranhão. Brazil J Vet Parasitol 14:59-63

3. Pound JM, George JE, Kammlah DM, Lohmeyer KH, Davey RB (2010) Evidence for role of white-tailed deer (Artiodactyla: Cervidae) in epizootiology of cattle ticks and southern cattle ticks (Acari: Ixodidae) in reinfestations along the Texas/Mexico border in South Texas: a review and update. J Econ Entomol 103:211-218

4. da Silva NB, Taus NS, Johnson WC, Mira A, Schnittger L, Valente JDM, Vidotto O, Masterson HE, Vieira TSWJ, Ueti MW, Vieira RFC (2018) First report of Anaplasma marginale infection in goats, Brazil. PLoS One 13:e0202140

5. Grisi L, Leite RC, Martins JRDS, de Barros ATM, Andreotti R, Cançado PHD, de León AAP, Pereira JB, Villela HS (2014) Reassessment of the potential economic impact of cattle parasites in Brazil. Rev Bras Parasitol Vet 23:150-156

6. Cafrune MM, Aguirre DH, Mangold AJ, Guglielmone AA (1995) Experimental studies of the rate of infection of Boophilus microplus eggs with Babesia bovis. Res Vet Sci 58:284-285

7. Dias Filho FDC, Coelho Linhares GF, Duarte SC, Lima Linhares DC (2007) Obtenção de isolados puros de Babesia bovis e Babesia bigemina a partir de larvas e ninfas de Boophilus microplus em bezerros neonatos privados de colostro. Rev Patol Trop 34:197-204

8. Futse JE, Ueti MW, Knowles DP, Palmer GH (2003) Transmission of Anaplasma marginale by Boophilus microplus: retention of vector competence in the absence of vector-pathogen interaction. J Clin Microbiol 41:3829-3834

9. de Castro JJ (1997) Sustainable tick and tickborne disease control in livestock improvement in developing countries. Vet Parasitol 71:77-97

10. EMBRAPA (2013) Saúde animal e impacto econômico são destaques no Simpósio Internacional sobre Controle de Carrapatos. https://www. embrapa.br/gado-de-corte/busca-de-noticias/-/noticia/1489479/saude -animal-e-impacto-economico-sao-destaques-no-simposio-internacio nal-sobre-controle-de-carrapatos. Accessed 2 Sept 2019

11. Nari A (1995) Strategies for the control of one-host ticks and relationship with tick-borne diseases in South America. Vet Parasitol 57:153-165

12. Perry B, Grace D (2009) The impacts of livestock diseases and their control on growth and development processes that are pro-poor. Philos Trans R Soc Lond B Biol Sci 364:2643-2655

13. Rodrigues DS, Leite RC (2013) Economic impact of Rhipicephalus (Boophilus) microplus: estimate of decreased milk production on a dairy farm. Arq Bras Med Vet Zootec 65:1570-1572

14. FAOSTAT. http://www.fao.org/faostat/en/\#rankings/commodities_by_ country. Accessed 30 Oct 2019

15. Barve N, Barve V, Jiménez-Valverde A, Lira-Noriega A, Maher SP, Peterson AT, Soberón J, Villalobos F (2011) The crucial role of the accessible area in ecological niche modeling and species distribution modeling. Ecol Model 222:1810-1819

16. Chevillon C, de Garine-Wichatitsky M, Barré N, Ducornez S, de Meeûs $\mathrm{T}$ (2013) Understanding the genetic, demographical and/or ecological processes at play in invasions: lessons from the southern cattle tick Rhipicephalus microplus (Acari: Ixodidae). Exp Appl Acarol 59:203-218

17. Estrada-Peña A, Acedo CS, Quílez J, Cacho E (2005) A retrospective study of climatic suitability for the tick Rhipicephalus (Boophilus) microplus in the Americas: climate and habitat for the cattle tick in the Americas. Glob Ecol Biogeogr 14:565-573

18. Peterson AT, Soberón J, Pearson RG, Anderson RP, Martínez-Meyer E, Nakamura M, Araújo MB (2011) Ecological Niches and geographic distributions. Princeton University Press, Oxford

19. Estrada-Peña A, Corson M, Venzal JM, Mangold AJ, Guglielmone A (2006) Changes in climate and habitat suitability for the cattle tick Boophilus 
microplus in its southern neotropical distribution range. JVector Ecol 31:158-167

20. Lynen G, Zeman P, Bakuname C, Di Giulio G, Mtui P, Sanka P, Jongejan F (2008) Shifts in the distributional ranges of Boophilus ticks in Tanzania: evidence that a parapatric boundary between Boophilus microplus and $B$. decoloratus follows climate gradients. Exp Appl Acarol 44:147-164

21. Marques R, Alves DMCC, Vicenzi N, Krolow TK, Krüger RF (2017) O aquecimento global irá alterar a distribuição geográfica de Lepiselaga crassipes (Diptera: Tabanidae), vetor de tripanossomíases em equinos, na Região Neotropical? Oecol Austr 21:27-41

22. Peterson AT, Lash RR, Carroll DS, Johnson KM (2006) Geographic potential for outbreaks of Marburg hemorrhagic fever. Am J Trop Med Hyg 75:9-15

23. Peterson AT (2009) Shifting suitability for malaria vectors across Africa with warming climates. BMC Infect Dis 9:59

24. McMichael AJ, Campbell-Lendrum DH, Corvalán CF, Ebi KL, Githeko AK, Scheraga JD, Woodward A (2003) Climate change and human health: risks and responses. World Health Organization, Geneva

25. dos Santos Vaz D (2010) Breves considerações sobre alterações climáticas, riscos ambientais e problemas de saúde. Hygeia 6:60-66

26. Elith J, Graham CH, Anderson RP, Dudík M, Ferrier S, Guisan A, Hijmans RJ, Huettmann F, Leathwick JR, Lehmann A, Li J, Lohmann LG, Loiselle BA, Manion G, Moritz C, Nakamura M, Nakazawa Y, Overton JMM, Peterson AT, Phillips SJ, Richardson K, Scachetti-Pereira R, Schapire RE, Soberón J, Williams S, Wisz MS, Zimmermann NE (2006) Novel methods improve prediction of species' distributions from occurrence data. Ecography 29:129-151

27. Peterson AT (2001) Predicting species' geographic distributions based on ecological niche modeling. Condor 103:599-605

28. Thuiller W, Richardson DM, Pysek P, Midgley GF, Hughes GO, Rouget M (2005) Niche-based modelling as a tool for predicting the risk of alien plant invasions at a global scale. Glob Change Biol 11:2234-2250

29. Grinnell J (1917) The niche-relationships of the California Thrasher. Auk 34:427-433

30. Carvalho BM, Rangel EF, Ready PD, Vale MM (2015) Ecological niche modelling predicts southward expansion of Lutzomyia (Nyssomyia) flaviscutellata (Diptera: Psychodidae: Phlebotominae), vector of Leishmania (Leishmania) amazonensis in South America, under climate change. PLoS One 10:e0143282

31. De Clercq EM, Estrada-Peña A, Adehan S, Madder M, Vanwambeke SO (2013) An update on distribution models for Rhipicephalus microplus in West Africa. Geospat Health 8:301-308

32. Leta S, Beyene TJ, De Clercq EM, Amenu K, Kraemer MUG, Revie CW (2018) Global risk mapping for major diseases transmitted by Aedes aegypti and Aedes albopictus. Int J Infect Dis 67:25-35

33. McIntyre KM, Setzkorn C, Hepworth PJ, Morand S, Morse AP, Baylis M (2017) Systematic assessment of the climate sensitivity of important human and domestic animals pathogens in Europe. Sci Rep 7:7134

34. Perkins TA, Siraj AS, Ruktanonchai CW, Kraemer MUG, Tatem AJ (2016) Model-based projections of Zika virus infections in childbearing women in the Americas. Nat Microbiol 1:16126

35. GBIF_-global biodiversity information facility. https://www.gbiforg/. Accessed 4 May 2020

36. SpeciesLink: Sistema de Informação Distribuído para Coleções Biológicas. http://splink.cria.org.br/. Accessed 4 May 2020

37. VectorMap. http://vectormap.si.edu/Tick Metadata.htm. Accessed 4 May 2020

38. Aiello-Lammens ME, Boria RA, Radosavljevic A, Vilela B, Anderson RP (2015) spThin: a R package for spatial thinning of species occurrence records for use in ecological niche models. Ecography 38:541-545

39. Burger TD, Shao R, Barker SC (2014) Phylogenetic analysis of mitochondrial genome sequences indicates that the cattle tick, Rhipicephalus (Boophilus) microplus, contains a cryptic species. Mol Phylogenet Evol 76:241-253

40. Labruna MB, Naranjo V, Mangold AJ, Thompson C, Estrada-Peña A, Guglielmone AA, Jongejan F, de la Fuente J (2009) Allopatric speciation in ticks: genetic and reproductive divergence between geographic strains of Rhipicephalus (Boophilus) microplus. BMC Evol Biol 9:46

41. Hijmans RJ, Cameron SE, Parra JL, Jones PG, Jarvis A (2005) Very high resolution interpolated climate surfaces for global land areas. Int J Climatol 25:1965-1978
42. Escobar LE, Lira-Noriega A, Medina-Vogel G, Peterson AT (2014) Potential for spread of the white-nose fungus (Pseudogymnoascus destructans) in the Americas: use of Maxent and NicheA to assure strict model transference. Geosp Health 9:221-229

43. Hitchcock LF (1955) Studies on the non-parasitic stages of the cattle tick, Boophilus microplus (Canestrini) (AcarinaL Ixodidae). Aust J Zool 3:295-311

44. CMIP5 (2012) Coupled Model Intercomparison Project (CMIP5). In: DDC AR5 Reference snapshot. https://www.ipcc-data.org/sim/gcm month ly/AR5/Reference-Archive.html?fbclid=IwAR3dUOeFLXFTtHX13\%20VDC -G-HHh5ZhHrt7FvW4hU1PWBwtiuD4B2IW2DwOuU. Accessed 4 May 2020

45. Ramirez-Villegas J, Jarvis A (2010) Downscaling Global Circulation Model Outputs: The Delta Method Decision and Policy Analysis Working Paper No. 1

46. GCM Downscaled Data Portal—Spatial Downscaling Data. http://www. ccafs-climate.org/data_spatial_downscaling/. Accessed 4 May 2020

47. Cobos ME, Peterson AT, Osorio-Olvera L, Jiménez-García D (2019) An exhaustive analysis of heuristic methods for variable selection in ecological niche modeling and species distribution modeling. Ecol Inform 53:100983

48. Cobos ME, Peterson AT, Barve N, Osorio-Olvera L (2019) kuenm: an R package for detailed development of ecological niche models using Maxent. PeerJ 7:e6281

49. Phillips JS, Anderson R, Dudĺk M, Schapire RE, Blair M (2017) Opening the black box: an open-source release of Maxent. Ecography 40:887-893

50. Warren DL, Seifert SN (2011) Ecological niche modeling in Maxent: the importance of model complexity and the performance of model selection criteria. Ecol Appl 21:335-342

51. Peterson AT, Papeş M, Soberón J (2008) Rethinking receiver operating characteristic analysis applications in ecological niche modeling. Ecol Model 213:63-72

52. Anderson RP, Raza A (2010) The effect of the extent of the study region on GIS models of species geographic distributions and estimates of niche evolution: preliminary tests with montane rodents (genus Nephelomys) in Venezuela. J Biogeogr 37:1378-1393

53. Owens HL, Campbell LP, Dornak LL, Saupe EE, Barve N, Soberón J, Ingenloff K, Lira-Noriega A, Hensz CM, Myers CE, Peterson AT (2013) Constraints on interpretation of ecological niche models by limited environmental ranges on calibration areas. Ecol Model 263:10-18

54. FAO (2014) Food and Agriculture Organization of the United Nations. In: Food and Agriculture Organization of the United Nations. http://www. fao.org/home/en/. Accessed 2 Sept 2019

55. Robinson TP, Wint GRW, Conchedda G, Van Boeckel TP, Ercoli V, Palamara E, Cinardi G, D'Aietti L, Hay SI, Gilbert M (2014) Mapping the global distribution of livestock. PLoS One 9:e96084

56. Estrada-Peña A, Estrada-Pena A (2001) Climate warming and changes in habitat suitability for Boophilus microplus (Acari: Ixodidae) in Central America. J Parasitol 87:978-987

57. Giles JR, Peterson A, Busch JD, Olafson PU, Scoles GA, Davey RB, Pound J, Kammlah DM, Lohmeyer KH, Wagner DM (2014) Invasive potential of cattle fever ticks in the southern United States. Parasit Vectors 7:189

58. Estrada-Peña A (1999) Geostatistics and remote sensing using NOAAAVHRR satellite imagery as predictive tools in tick distribution and habitat suitability estimations for Boophilus microplus (Acari: Ixodidae) in South America. Vet Parasitol 81:73-82

59. Guglielmone AA, Giorgi R, Sodiro A, Gay R, Canal A, Mangold AJ, Peña AE (2003) Aptitud ecológica de los Departamentos Castellanos y Las Colonias, Santa Fe, para sustentar hipotéticas poblaciones de la garrapata común del vacuno, Boophilus Microplus (Acari: Ixodidae). Rev Invest Agro 32:75-92

60. de Souza FS, Botelho MCSN, Lisbôa RS (2012) Aplicação do geoprocessamento na análise da distribuição espaço-temporal de áreas potenciais à ocorrência simultânea de dermatobiose e carrapato Rhipicephalus microplus em bovinos no Município de Seropédica, RJ, Brasil. Arq Inst Biol 79:17-23

61. Cançado PHD, Zucco CA, Piranda EM, Faccini JLH, Mourão GM (2009) Rhipicephalus (Boophilus) microplus (Acari: Ixodidae) as a parasite of pampas deer (Ozoctoceros bezoarticus) and cattle in Brazil's Central Pantanal. Rev Bras Parasitol Vet 18:42-46 
62. Farias NA, Stobbe NS, Chistovão ML, Perri SHV, Costa AJ (1995) Influência das condições climáticas da Região Noroeste do Estado de São Paulo, Brasil, sobre os estágios não-parasitários do carrapato Boophilus microplus (Canestrini, 1887) (Acari:ixodidae). Rev Bras Parasitol Vet 4:67-77

63. Sutherst RW, Moorhouse DE (1972) The seasonal incidence of Ixodid ticks on cattle in an elevated area of South-Eastern Queensland. Aust J Agric Res 23:195-204

64. Davey RB, Cooksey LM, Despins JL (1991) Survival of larvae of Boophilus annulatus, Boophilus microplus, and Boophilus hybrids (Acari: Ixodidae) in different temperature and humidity regimes in the laboratory. Vet Parasitol 40:305-313

65. Garris Gl, Popham TW, Zimmerman RH (1990) Boophilus microplus (Acari: Ixodidae): oviposition, egg viability, and larval longevity in grass and wooded environments of Puerto Rico. Environ Entomol 19:66-75

66. Kivaria FM (2006) Estimated direct economic costs associated with tickborne diseases on cattle in Tanzania. Trop Anim Health Prod 38:291-299
67. Rodríguez-Vivas RI, Grisi L, de León AA, Villela HS, de Jesús Torres-Acosta JF, Sánchez HF, Salas DR, Cruz RR, Saldierna F, Carrasco DG (2017) Potential economic impact assessment for cattle parasites in Mexico Review. Rev Mex Cienc Pecu 8:61-74

68. Ghosh S, Azhahianambi P, de la Fuente J (2006) Control of ticks of ruminants, with special emphasis on livestock farming systems in India: present and future possibilities for integrated control - a review. Exp Appl Acarol 40:49-66

69. Vetrivel D, Pandian ASS, Selvakumar KN, Shree JS (2017) A study on the prevalence of babesiosis in north eastern agro-climatic zone of Tamil Nadu, India. J Entomol Zool Stud 5:1271-1273

\section{Publisher's Note}

Springer Nature remains neutral with regard to jurisdictional claims in published maps and institutional affiliations.
Ready to submit your research? Choose BMC and benefit from:

- fast, convenient online submission

- thorough peer review by experienced researchers in your field

- rapid publication on acceptance

- support for research data, including large and complex data types

- gold Open Access which fosters wider collaboration and increased citations

- maximum visibility for your research: over $100 \mathrm{M}$ website views per year

At BMC, research is always in progress.

Learn more biomedcentral.com/submissions 